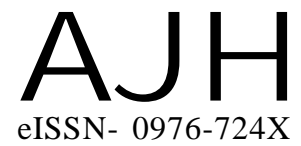

Received : 06.02.2016

Revised : 07.05.2016

Accepted : 16.05.2016
Members of the Research Forum

Associated Authors:

${ }^{1}$ Department of Floriculture and

Landscape Gardening, Tamil Nadu

Agricultural University,

COIMBATORE (T.N.) INDIA

${ }^{2}$ Department of Seed Science and

Technology, Tamil Nadu

Agricultural University,

COIMBATORE (T.N.) INDIA
Author for correspondence : M. DHIVYA

Department of Floriculture and Landscape Gardening, Tamil Nadu Agricultural University,

COIMBATORE (T.N.) INDIA

Email : shiny.divya@gmail.com
THEASIAN JOURNALOF HORTICULTURE

Volume 11 | Issue 1 | June, 2016 | 176-179

Visit us -www.researchjournal.co.in

\title{
Physiological efficiency of succulents under different growing environments in tropical condition
}

\section{DHIVYA, R. SANKARANARAYANAN ${ }^{1}$ AND G. DILEEP KUMAR ${ }^{2}$}

ABSTRACT : Investigations were undertaken to study the physiological effectiveness of different ornamental succulents under tropical condition. Six species of succulents were evaluated under four different growing environments. Results showed that the performance of succulents grown under conservatory house condition was found to be performed well and ideal with respect to chlorophyll, carotenoids, relative water content and photosynthetic rate than other growing environments. The succulent species viz., Haworthia limifolia, Monadenium lugardiae and Aloe juvenna were the most suitable species for growing under conservatory house condition due to its high nocturnal $\mathrm{CO}_{2}$ uptake and cell sap acidification which possess CAM metabolism. CAM involves nocturnal $\mathrm{CO}_{2}$ uptake and fixation by cytosolic phosphoenolpyruvate carboxylase into malic acid that is stored in the vacuole causing nocturnal cell sap acidification. During the subsequent light period, malic acid is released from the vacuole in the form of malate that is then decarboxylated leading to deacidification of cell sap, formation of pyruvate or phosphoenolpyruvate and liberation of $\mathrm{CO}_{2}$. Repeated acidification and deacidification cycles represent a characteristic physiological feature of CAM metabolism in succulents which is best suited for xeric environment and possess high photosynthetic efficiency.

KEY WORDS : Succulents, Chlorophyll, Photosynthetic rate, CAM metabolism

HOW TO CITE THIS ARTICLE : Dhivya, M., Sankaranarayanan, R. and Kumar, G. Dileep (2016). Physiological efficiency of succulents under different growing environments in tropical condition. Asian J. Hort., 11(1) : 176-179, DOI : 10.15740/HAS/TAJH/11.1/176-179. 